\title{
Aktivitas Fisik Saat Istirahat, Intensitas Penggunaan Smartphone, dan Kejadian Obesitas Pada Anak SD Full day School (Studi di SD AI Muslim Sidoarjo)
}

\section{Recess Physical Activity, Intensity of Smartphone Usage and Obesity among Full Day School Students}

\author{
Sakinah Ramadhani*, Luki Mundiastuti ${ }^{1}$, Trias Mahmudiono²
}

\begin{abstract}
ABSTRAK
Latar Belakang: Peningkatan obesitas disebabkan kurang melakukan aktivitas fisik dan kelebihan asupan makanan. Kebiasaan menonton tv, bermain komputer, dan smartphone yang dikaitkan dengan prevalensi obesitas saat ini.

Tujuan: Menganalisis hubungan aktivitas fisik saat istirahat dan intensitas penggunaan smartphone, pada anak dengan status obesitas dan status gizi normal di SD Full Day School.

Metode: Mengunakan case control dengan 110 anak Sekolah Dasar yang terdiri dari dua kelompok yaitu kelompok status gizi normal sebanyak 55 responden dan kelompok status obesitas sebanyak 55 responden. Pengambilan sampel dilakukan dengan propotional random sampling. Penelitian ini akan membandingkan aktivitas fisik saat istirahat, dan intensitas penggunaan smartphone pada status obesitas dan status gizi normal. Analisis data penelitian ini menggunakan uji chi-square dan regresi logistik.

Hasil: Hasil penelitian menunjukkan bahwa terdapat hubungan antara aktivitas fisik saat istirahat pertama dengan obesitas $(p=0,010)$ dan didapatkan nilai OR sebesar 0,059 dengan $\mathrm{Cl} 95 \%(0,011$ $0,509)$ yang berarti bahwa siswa yang melakukan aktivitas fisik istirahat pertama berisiko 0,059 kali lebih kecil untuk mengalami obesitas. Sedangkan untuk aktivitas fisik saat istirahat kedua $(p=0,748)$, intensitas penggunaan smartphone saat weekdays $(p=0,225)$, dan intensitas penggunaan smartphone saat weekend $(p=0,246)$ tidak terdapat hubungan dengan kejadian obesitas.

Kesimpulan: Aktivitas fisik saat istirahat pertama berhubungan dengan kejadian obesitas pada anak SD Full Day School. Sedangkan untuk aktivitas istirahat kedua, intensitas penggunaan smartphone saat weekdays dan weekend tidak berhubungan dengan kejadian obesitas pada anak SD Full Day School.
\end{abstract}

Kata Kunci: obesitas, aktivitas fisik saat istirahat, dan intensitas penggunaan smartphone.

\section{ABSTRACT}

Background: obesity prevalence in elementary school student increased due to low physical activity rate also excessive food intake. The habit of watching $t v$, using computer and smartphone is also related to this obesity prevalence.

Objective: Analyze physical activity at recess, intensity of smartphone use, and incidence of obesity among students at Full Day Elementary School

Method: Using a case control with 110 elementary school children consisting of two groups, namely the normal nutritional status group of 55 respondents and the obesity status group of 55 respondents.Sampling was done by propotional random sampling. This study will compare physical 
activity at rest, and the intensity of smartphone use on obesity status and normal nutritional status. Analysis of this study data using chi-square test and logistic regression.

Results : The results showed that there was a relationship between physical activity during the first break with obesity $(p=0.010)$ and an OR value of 0.059 with a $95 \% \mathrm{Cl}(0.011-0.509)$ which meant that students who did physical activity first break by sitting at risk 0.059 times less to be obese. As for physical activity at the second rest $(p=0.748)$, intensity of smartphone usage during weekdays $(p=0.225)$, and intensity of smartphone use when there was no correlation with the incidence of obesity. Conclusion: Physical activity at the first break was related to the incidence of obesity in elementary school children Full Day School. As for the second resting activity, the intensity of smartphone usage during weekdays and weekends is not related to the incidence of obesity in elementary school children Full Day School.

Keywords: obesity, physical activity during break, smartphone usage intensity

\footnotetext{
*Koresponden:

sakinahramadhani355@gmail.com

${ }^{1}$ Akademi Gizi Surabaya, Indonesia

${ }^{2}$ Departemen Gizi Kesehatan FKM UNAIR
}

\section{PENDAHULUAN}

Obesitas merupakan permasalahan kesehatan yang terjadi di negara maju dan berkembang. Prevalensi overweight dan obesitas pada anak di dunia sebesar 6,7\% pada tahun 2010. Di Afrika prevalensi anak overweight dan obesitas sebesar 8,5\% . Sedangkan Di Asia prevalensi anak overweight dan obesitas sebesar 4,9\%. Berdasarkan Data Obesity Update 2017, prevalensi obesitas pada anak laki-laki usia 3-17 tahun di United States adalah $20 \%$. Sedangkan untuk anak perempuan usia 3-17 tahun di United States adalah $18 \%^{1}$. Di Indonesia, prevalensi obesitas pada anak terus mengalami peningkatan. Hasil Riset Kesehatan Dasar tahun 2007, menunjukkan prevalensi gizi lebih pada anak usia sekolah dengan jenis kelamin laki-laki adalah 9,5\%. Sedangkan prevalensi anak usia sekolah dengan jenis kelamin perempuan adalah $6,4 \%{ }^{2}$. Berdasarkan Riset Kesehatan Dasar 2010, menunjukkan prevalensi status gizi lebih Nasional pada anak sekolah (6-12 tahun) yaitu $9,2 \%^{3}$. Pada tahun 2013 prevalensi gizi lebih juga mengalami peningkatan menjadi $18,8 \%$. Di jawa timur jumlah status gizi lebih sebesar $12,4 \%$ pada tahun 2010 dan melebihi prevalensi Nasional pada tahun 2013 sebesar 19,9\% ${ }^{4}$. Penelitian Yaqin (2014) menyebutkan di SDN Ploso II Kecamatan Tambaksari Surabaya, prevalensi gizi lebih pada anak sekolah sebesar $20 \%$ dimana prevalensi tersebut melebihi prevalensi Kota Surabaya sebesar $8,9 \%{ }^{5}$.

Penyebab obesitas dapat terjadi dikarenakan kurang melakukan aktivitas yang kurang dan kelebihan asupan makanan. Semakin meningkatnya teknologi zaman sekarang membawa dampak anak-anak lebih memilih waktu luang sehari-hari dengan bermain smartphone, menonton televisi, atau vidio games dibandingkan dengan bermain diluar rumah terutama saat hari libur sekolah (weekend) ${ }^{7}$. Menurut American Academy of Pediatrics tahun 2006, intensitas penggunaan smartphone yang paling baik yaitu $<2$ jam ${ }^{8}$. Namun rekomendasi tersebut tidak sesuai dengan kebiasaan yang dilakukan oleh anak setiap harinya sesuai dengan penelitian di Kanada bahwa penggunaan media elektronik pada anak mencapai $\geq 4$ jam $^{9}$. Dijelaskan pada anak SD sering menggunakan media elektronik akan mengurangi aktivitas fisiknya sehingga energi yang dikeluarkan akan sedikit ${ }^{10}$. Penelitian yang dilakukan di Pakistan pada anak usia 6-10 tahun dan di Portugal menunjukkan bahwa rendahnya olahraga akan meningkatkan energi yang tidak digunakan menjadi lemak dalam tubuh $^{11}$. Dengan berkembangnya teknologi yang semakin pesat, seperti halnya penggunaan smartphone pada anak sekolah dasar menyebabkan anak malas melakukan aktivitas fisik ${ }^{12}$. Malas melakukan aktivitas fisik mengakibatkan energi yang seharusnya digunakan untuk beraktivitas fisik 
tidak diperlukan sehingga kemudian energi tersebut disimpan sebagai timbunan lemak dan akhirnya akan menimbulkan obesitas ${ }^{13}$. SD full day school dipilih dalam penelitian ini dikarenakan sekolah menerapkan kurang lebih 9 jam belajar dalam sehari, yakni mulai jam 07.00 WIB sampai dengan jam 16.00 WIB. Hal ini berarti siswa yang lebih lama tinggal di sekolah dan mengurangi waktu bermain smartphone $^{14}$.

Berdasarkan fenomena diatas maka penulis tertarik untuk melakukan penelitian tentang Aktivitas Fisik Saat Istirahat, Intensitas Penggunaan Smartphone, dan Kejadian Obesitas Pada Anak SD Full day School (Studi di SD AI Muslim Sidoarjo). Tujuan dari penelitian ini adalah untuk menganalisis aktivitas fisik saat istirahat, intensitas penggunaan smartphone, dan kejadian obesitas pda anak SD Full day School (Studi di SD Al Muslim Sidoarjo).

\section{METODE}

Penelitian ini adalah penelitian obeservasional analitik dengan desain studi case control. Terdiri dari dua kelompok yaitu anak dengan status obesitas (Z-Scores $>+2$ sd) dan gizi normal (-2sd<Z-Scores $<+1 s d)$. Penelitian ini menggunakan propotional random sampling dikarenakan teknik pengambilan sampel digunakan untuk memperoleh sampel dari tiap sub populasi yang jumlahnya akan disesuaikan dengan jumlah anggota dari masing-masing sub populasi secara acak. Variabel dependen dari penelitian ini adalah status gizi, sedangkan untuk variabel independen adalah aktivitas fisik saat istirahat dan intensitas penggunaan smartphone. Penelitian ini dilakukan di SD Al Muslim Sidoarjo pada bulan Mei - Juli 2018. Siswa kelas IV dan siswa kelas V Al Muslim Sidoarjo merupakan populasi dari penelitian ini. Kriteria inklusi dari penelitian ini adalah orang tua siswa yang bersedia untuk berpartisipasi dalam penelitian ini dengan menandatangani informed consent, dan siswa kelas IV dan V yang memiliki akses smartphone di rumah. Siswa yang sakit parah sehingga tidak dapat mengikuti penelitian merupakan kriteria eksklusi dalam penelitian ini.
Pengumpulan data dilakukan dengan metode wawancara menggunakan kuisoner aktivitas fisik yaitu Physical Activity Questionnaire (PAQ-C) kuisoner ini sudah pernah digunakan pada penelitian sebelumnya. Dalam kusioner PAQ-C terdiri dari 10 pertanyaan yaitu pertanyaan pertama olahraga di waktu luang, pertanyaan kedua selama pelajaran olahraga seberapa sering anda sangat aktif, pertanyaan ketiga aktivitas yang dilakukan saat istirahat pertama, pertanyaan keempat aktivitas yang dilakukan saat istirahat kedua, pertanyaan kelima setelah pulang sekolah melakukan olahraga, pertanyaan keenam saat sore hari melakukan olahraga, pertanyaan ketujuh minggu kemarin melakukan olahraga atau tidak, pertanyaan kedepalan pernyataan yang sesuai dengan responden, pertanyaan kesembilan malakukan olahraga selama seminggu, dan pertanyaan kesepuluh selama melakukan aktivitas fisik apa pernah terhambat.

Dari ke 10 pertanyaan tersebut cara penilainnya dengan menjumlahkan tiap pilihan jawaban yaitu $A, B, C, D$, dan E. Hasil tersebut akan digunakan sebagai nilai PAQ-C tiap responden ${ }^{14}$. Setelah itu dicari median dari total $P A Q-C$ pada tiap responden dan nilai median tersebut akan menjadi standart PAQ-C. Setelah dihitung median didapatkan 71,5 sehingga menggunakan skala data nominal < (median) 71,5 dan $\geq$ (median) 71,5. Dari ke 10 pertanyaan tersebut yang digunakan hanya 2 variabel yaitu aktivitas fisik saat istirahat pertama dan aktivitas fisik saat istirahat kedua. Dikarenakan pada variabel aktivitas fisik istirahat pertama memiliki hubungan yang signifikan dengan obesitas, lalu untuk aktviitas fisik istirahat kedua dibandingkan dengan istirahat pertama yang signifikan dengan obesitas. sedangkan untuk variabel lainnya tidak digunakan dikarenakan tidak memiliki hubungan yang signifikan dengan obesitas. Sedangkan untuk intensitas penggunaan smartphone diukur dengan menggunakan kuisoner recall intensitas penggunaan smartphone yang di recall penggunaan smartphone dirumah karna disekolah siswa tidak diperbolehkan membawa smartphone dengan skala data nominal $<2$ jam per hari dan $\geq 2$ jam per hari. Recall smartphone ini dilakukan selama 2 kali saat weekdays dan 
weekend dengan menanyakan penggunaan smartphone dengan waktu mundur seperti halnya recall makanan. Recall smartphone ini digunakan untuk melihat apa saja yang digunakan dan waktu yang digunakan.

Penelitian ini sudah mendapatkan izin dari Komisi Etik Fakultas Kesehatan Masyarakat Universitas Airlangga Surabaya dengan Nomor 215-KEPK tanggal 2 Mei 2018.

\section{HASIL DAN PEMBAHASAN}

Kejadian obesitas paling banyak pada usia 10 tahun (23,6\%). Pada usia 6-12 tahun anak mengalami perkembangan dan pertumbuhan yang lebih stabil dibandingkan dengan bayi dan balita, Sehingga berbagai masalah gizi dapat terjadi salah satunya yaitu obesitas. Proporsi obesitas pada penelitian ini lebih banyak pada siswa laki-laki 33,6\% dibandingkan dengan siswa perempuan $16,3 \%$, penelitian ini juga sejalan dengan penelitian yang dilakukan Sartika (2011) $)^{15}$ bahwa anak laki-laki banyak mengalami status gizi lebih dibandingkan dengan anak perempuan ${ }^{15}$. Anak dengan kategori status gizi lebih memiliki tingkat leptin yang lebih tinggi daripada anak dengan IMT normal. Tingkat leptin akan mencapai puncak saat awal pubertas dimana leptin merupakan sinyal penting yang bertanggung jawab terhadap pubertas atau growt spurt pada anak laki-laki ${ }^{10}$. Anak yang sudah mengalami growth spurt biasanya tubuhnya lebih banyak lemak dan berat hingga usia 11 tahun yang kelebihan lemak tersebut akan menurun saat umur 12 tahun sehingga digantikan oleh otot dan tulang ${ }^{16}$. Sesuai dengan penelitian yang dilakukan oleh Nadya ${ }^{17}$, menunjukkan bahwa anak yang berusia 10 tahun lebih banyak yang mengalami obesitas ${ }^{17}$. Leptin merupakan suatu stimulan nafsu makan yang diekskresi di usus dan di hipotalamus. Leptin akan dilepaskan oleh selsel lemak dan akan mempengaruhi neuronneuron yang terdapat pada hipotalamus dalam mengatur perilaku makan. Terdapat dua jenis pengaturan yaitu jangka panjang dan jangka pendek. Pada jangka pendek pengaturan menyebabkan seseorang akan merasa kenyang dan akan menghentikan aktivitas. Sedangkan untuk pengaturan jangka penjang akan melibatkan infromasi dari tempat cadangan energi yaitu jaringan adipose.

Tabel 1. Karakteristik Anak Berdasarkan Umur dan Jenis Kelamin

\begin{tabular}{lcccc}
\hline Karakteristik & \multicolumn{2}{c}{ Obesitas } & \multicolumn{2}{c}{ Normal } \\
\cline { 2 - 5 } & $\mathbf{n}$ & $\%$ & $\mathbf{n}$ & $\%$ \\
\hline Umur & & & & \\
9 Tahun & 7 & 6,36 & 14 & 12,7 \\
10 Tahun & 26 & 23,6 & 22 & 20 \\
11 Tahun & 18 & 16,3 & 19 & 17,2 \\
12 Tahun & 4 & 3,63 & 0 & 0 \\
\hline Jenis & & & & \\
Kelamin & & & & \\
$\quad$ Laki-Laki & 37 & 33,6 & 29 & 26,3 \\
$\quad$ Perempuan & 18 & 16,3 & 26 & 23,6 \\
\hline
\end{tabular}

Berdasarkan tabel 2, tidak terdapat hubungan siginifikan antara penggunaan smartphone saat weekdays dengan kejadian obesitas di mana nilai $p=0,225 \quad(>0,05)$. Penggunaan smartphone tidak signifikan dikarenakan saat weekdays responden banyak menggunaan smartphone < 2jam baik pada kelompok obesitas maupun tidak obesitas. Saat weekdays sekolah memiliki peraturan bahwa siswa tidak diperbolehkan membawa smartphone ke sekolah dan peraturan tersebut juga berlaku pada wali murid. Wali murid sangat membatasi penggunaan smartphone saat weekdays yang dapat menganggu aktivitas belajar anak meraka dan ada pula wali murid yang memperbolehkan menggunakan smartphone saat weekend saja. Sedangkan saat weekend responden lebih lama menggunakan smartphone $\geq 2$ jam dibandingkan saat weekdays. Hasil penelitian ini sejalan dengan penelitian Isna (2014), bahwa anak-anak dalam kategori normal maupun obesitas rata-rata menggunakan smartphone lebih lama pada weekend dibandingkan saat weekdays ${ }^{18}$.

Berdasarkan pada tabel 3, terdapat hubungan antara aktivitas fisik istirahat pertama dengan kejadian obesitas dengan nilai $\mathrm{p}=0,010(<0,05)$. Didapatkan nilai OR sebesar 0,059 dengan $\mathrm{Cl} 95 \%(0,011-0,509)$ yang berarti bahwa siswa yang melakukan aktivitas fisik istirahat pertama berisiko 0,059 kali lebih kecil untuk mengalami obesitas. 
Tabel 2. Hubungan Intenstas Penggunaan Smartphone saat Weekdays dan Weekend dengan Kejadian Obesitas pada anak SD Full Day

\begin{tabular}{|c|c|c|c|c|c|c|c|c|}
\hline \multirow[t]{2}{*}{ Variabel } & \multicolumn{2}{|c|}{ Obesitas } & \multicolumn{2}{|c|}{ Normal } & \multirow[t]{2}{*}{$p$-value } & \multirow{2}{*}{$\begin{array}{l}\text { Odds } \\
\text { ratio }\end{array}$} & \multicolumn{2}{|c|}{$95 \% \mathrm{Cl}$} \\
\hline & $\mathrm{n}$ & $\%$ & $n$ & $\%$ & & & lower & upper \\
\hline \multicolumn{9}{|c|}{ Intensitas } \\
\hline \multicolumn{9}{|c|}{ Penggunaan } \\
\hline \multicolumn{9}{|c|}{ Smartphone saat } \\
\hline \multicolumn{9}{|c|}{ Weekdays } \\
\hline$<2$ jam & 47 & 42,7 & 42 & 38,1 & $P=0,225$ & 0,861 & 0,197 & 1,409 \\
\hline$>2 \mathrm{jam}$ & 8 & 7,27 & 13 & 11,8 & & & & \\
\hline \multicolumn{9}{|c|}{ Intensitas } \\
\hline \multicolumn{9}{|c|}{ Penggunaan } \\
\hline \multicolumn{9}{|c|}{ Smartphone saat } \\
\hline \multicolumn{9}{|c|}{ Weekend } \\
\hline <2jam & 26 & 23,6 & 30 & 27,2 & $P=0,246$ & 1,304 & 0,284 & 1,330 \\
\hline$>2$ jam & 29 & 26,3 & 35 & 31,8 & & & & \\
\hline
\end{tabular}

Signifikansi berdasarkan uji Chi Square dengan p-value $<0,05$

Tabel 3. Hubungan Aktivitas Fisik saat Istirahat Pertama dan Istirahat Kedua dengan Kejadian Obesitas pada anak SD Full Day

\begin{tabular}{|c|c|c|c|c|c|c|c|c|}
\hline \multirow[t]{2}{*}{ Variabel } & \multicolumn{2}{|c|}{ Obesitas } & \multicolumn{2}{|c|}{ Normal } & \multirow[t]{2}{*}{$p$-value } & \multirow{2}{*}{$\begin{array}{l}\text { Odds } \\
\text { Ratio }\end{array}$} & \multicolumn{2}{|c|}{$95 \% \mathrm{Cl}$} \\
\hline & $n$ & $\%$ & $n$ & $\%$ & & & Lower & Upper \\
\hline \multicolumn{9}{|l|}{ Istirahat Pertama } \\
\hline Duduk-duduk & 32 & 29 & 19 & 17,2 & & & & \\
\hline $\begin{array}{l}\text { Berdiri disekitar } \\
\text { kelas }\end{array}$ & 0 & 0 & 1 & 0,9 & & & & \\
\hline $\begin{array}{l}\text { Jalan-jalan } \\
\text { berkeliling sekolah }\end{array}$ & 1 & 0,9 & 10 & 9,09 & $P=0,010$ & 0,059 & 0,011 & 0,501 \\
\hline $\begin{array}{l}\text { Kadang lari-lari dan } \\
\text { bermain }\end{array}$ & 3 & 2,72 & 7 & 6,36 & & & & \\
\hline $\begin{array}{l}\text { Sering Berlari dan } \\
\text { Bermain }\end{array}$ & 19 & 17,2 & 18 & 16,3 & & & & \\
\hline \multicolumn{9}{|l|}{ Istirahat Kedua } \\
\hline $\begin{array}{l}\text { a. Duduk-duduk } \\
\text { b. Berdiri }\end{array}$ & 16 & 14,5 & 17 & 15,4 & & & & \\
\hline disekitar kelas & 1 & 0,9 & 0 & 0 & & & & \\
\hline $\begin{array}{l}\text { c. Jalan-jalan } \\
\text { berkeliling } \\
\text { sekolah }\end{array}$ & 6 & 5,45 & 7 & 6,36 & $P=0,748$ & 1,304 & 0,842 & 1,425 \\
\hline \multicolumn{9}{|l|}{$\begin{array}{ll}\text { d. Kadang lari- } \\
\text { lari } & \text { dan }\end{array}$} \\
\hline bermain & 16 & 14,5 & 12 & 10,9 & & & & \\
\hline $\begin{array}{l}\text { e. Sering Berlari } \\
\text { dan Bermain }\end{array}$ & 16 & 14,5 & 19 & 17,2 & & & & \\
\hline
\end{tabular}

Signifikansi berdasarkan uji Chi Square dengan p-value $<0,05$

Dari hasil OR menunjukkan hasil yang bertolak belakang dengan teori yang ada. Seperti penelitian yang dilakukan oleh Risa (2017), bahwa kurang melakukan aktivitas fisik dapat menyebabkan obesitas ${ }^{19}$. Tetapi dari hasil penelitian ini bertolak belakang dengan teori bahwa melakukan aktivitas fisik dengan dudukduduk dapat mencegah terjadinya obesitas. Aktivitas fisik istirahat pertama berhubungan dikarenakan saat istirahat pertama tidak 
terdapat jadwal kegiatan sehingga anak-anak melakukan aktivitas sesuai dengan yang diinginkannya. Sedangkan untuk aktivitas pada istirahat kedua tidak terdapat hubungan antara aktivitas fisik istirahat kedua dengan kejadian obesitas dengan nilai $p=0,748$ ( $>0.05)$. Pada istirahat kedua siswa dengan obesitas banyak yang melakukan kegiatan berlari dan bermain $(31,8 \%)$. Pada istirahat pertama responden hanya melakukan aktivitas duduk-duduk saja sedangkan pada istirahat kedua responden banyak melakukan aktviitas fisik dikarenakan pada istirahat kedua terdapat jadwal yang harus dilakukan seperti makan siang bersama, dan sholat dhuhur bersama. Sesuai dengan penelitian yang dilakukan oleh Ramstetter $C L$ et al $(2011)^{20}$, bahwa siswa-siswi harus tetap melakukan aktivitas fisik untuk memerangi terjadinya obesitas ${ }^{20}$.

Sekolah juga dapat mengadakan kegiatan bermain bersama siswa dengan beberapa guru pada jam istirahat pertama dengan melibatkan siswa-siswi dalam melakukan aktivitas fisik sehingga siswa-siswi dapat mengurangi risiko obesitas ${ }^{10}$. Hal ini juga sejalan dengan penelitian yang dilakukan oleh Centers for Disease Control and Prevention, bahwa sekolah mempengaruhi kegiatan aktivitas fisik anak sehingga perlu adanya penambahan fasilitas yang dapat memenuhi kebutuhan aktivitas fisik anak saat jam istirahat pertama dan jam istirahat kedua. Hal-hal yang dapat dilakukan untuk menunjang aktivitas fisik anak dengan menambahkan tempat bermain dan peralatan yang sesuai dengan aktivitas yang akan dilakukan. Setelah di tambahkan beberapa fasilitas aktivitas fisik, sekolah juga harus menjaga fasilitas tersebut seperti halnya lapangan, dan kolam renang supaya anak-anak dapat terus melakukan aktvitas fisik ${ }^{21}$.

Kelemahan dalam penelitian ini saat pengisian kuisoner berlangsung beberapa dari responden diganggu oleh teman sehingga responden tidak dapat fokus dalam menjawab pertanyaan yang diajukan. Kelebihan dalam penelitian ini adalah variabel intensitas penggunaan smartphone yang dikaitkan dengan kejadian obesitas dikarenakan pada penelitian sebelumnya masih sedikit yang meneliti tentang penggunaan smartphone dengan kejadian obesitas pada anak SD Full Day School.

\section{KESIMPULAN}

Aktivitas fisik saat istirahat pertama berhubungan dengan kejadian obesitas pada anak SD Full Day School. Sedangkan aktivitas fisik istirahat kedua dan intensitas penggunaan smartphone tidak berhubungan dengan kejadian obesitas.

\section{ACKNOWLEDGEMENT}

Peneliti mengucapkan terimakasih kepada seluruh responden, Kepala Sekolah SD Al Muslim Sidoarjo yang telah mengijinkan saya melakukan penelitian di sekolah tersebut.

\section{REFERENSI}

1. Hamann, A. Obesity Update 2017. Diabetologe 135, 331-334 (2017).

2. Indonesia, K. K. R. Riset Kesehatan Dasar 2007. in Badan Penelitian dan Pengembangan Kesehatan Kementrian Kesehatan RI (2007).

3. Indonesia, K. K. R. Riset Kesehatan Dasar 2010. in Penelitian dan Pengembangan Kesehatan Kementrian Kesehatan RI (2010).

4. Indonesia, K. K. R. Angka Kecukupan Gizi Yang Dianjurkan Bagi Bangsa. in 5-10 (2013).

5. Yaqin, M. K. dan Nurhayati, F. Prevalensi Obesitas Pada Anak Usia SD Menurut IMT/U Di SD Negeri Ploso No 173 Surabaya. J. Pendidik. Olahraga dan Kesehat. 2, 114-118 (2014).

6. Fajar, S.T, Huriyati, E. \& I. Intensitas Penggunaan Gadget dan Obesitas Anak Prasekolah. Ber. Kedokt. Masy. 799-804 (2017).

7. Haidar, A. \& Panunggal, B. Perbedaan Jumlah Asupan Energi, Lemak, Serat Dan Natrium Berdasarkan Kategori Screen-Time viewing pada Anak Obesitas Usia 9-12 Tahun. J. Nutr. Coll. 403-310 (2013).

8. (US), A. A. O. P. Children, Adolescents and Television. Comm. Public Educ. 2, 423 (2006). 
9. De, O.M., Blössner M., \& B. E. Global Prevalence \& Trends of Overweight and Obesity among Preschool Children. Am. J. Clin. Nutr. 92, 57-64 (2010).

10. Dai, Y.L., Liang, L., Gong, C.X., Xiong, F., Luo, F.H., Liu, G.L., \& Chen, S. K. Association between obesity and sexual maturation in Chinese children: a muticenter study. Int. J. Obes. 38, 13121316 (2014).

11. Gouw, D., Klepp, K. I., Vignerova, J., Lien, N., Steenhuis, I. H., \& Wind, M. Association between obesity and sexual maturation in Chinese children: a muticenter study. Public Heal. Nutr 13, 1701 (2010).

12. Duncan, S., Duncan, E. K., Fernandes, R. A., Buonani, C., Bastos, K., Segatto, A., Codogno, J. S., Gomes, I. C., \& Freitas, I. F. Modifiable Risk Factors for Overweight and Obesity in Children and Adolescents from São Paulo, Brazil. BioMed Cent. Public Heal. 7, 585 (2011).

13. Haidar, A. \& Panunggal, B. Perbedaan Jumlah Asupan Energi, Lemak, Serat Dan Natrium Berdasarkan Kategori Screen-Time viewing pada Anak Obesitas Usia 9-12 Tahun. J. Nutr. Coll. 3, 403-410 (2013).

14. Kowalski, C. \& D. The Physical Activity Questionnaire for Older Children ( PAQ-
C) and Adolescents (PAQ-A) Manual. Coll Kinesiol Univ Saskatchewan (2004).

15. Sartika, R. A. D. Faktor Risiko Obesitas pada Anak 5-15 Tahun di Indonesia. J. Makara Kesehat. 15, (2011).

16. Indonesia, K. K. republik. Angka Kecukupan Gizi Yang Dianjurkan Bagi Bangsa. in 5-10 (2013).

17. Nadya, D.N.E. \& Wirjatmadi, B. Hubungan Aktivitas Fisik dan Asupan Gizi Dengan Status Gizi Lebih Pada Anak Usia Sekolah Dasar di Sdn Ketabang 1 Kota Surabaya Tahun 2017. Amerta Nutr. 97-105 (2018).

18. Isna, N. Screen Time, Asupan Lemak dan Serat Serta Status Gizi Siswa Sekolah Dasar Di Kota Bogor. (Institut Pertanian Bogor, 2014).

19. Anggi, R. Hubungan Aktivitas Fisik Dengan Obesitas Pada Anak Kelas 2 DI SD Muhammadiyah Mlangi Sleman. (Universitas Aisyiyah Yogyakarta, 2017).

20. Ramstetter $\mathrm{CL}$, Murray $\mathrm{R}$, \& Garner, A. The Crucial Role of Recess in Schools. J. Sch. Health 80, 517-526 (2010).

21. Prevention, C. for D. C. School health guidelines to promote healthy eating and physical activity. MMWR Recomm 60 (2011). 